\title{
REVIEW : EFFECT OF RED CABBAGE JUICE (BRASSICA OLERACEA VAR. CAPITATA F. RUBRA) ON SGPT LEVEL
}

\author{
${ }^{1}$ Hesty Wahyuningsih, ${ }^{2}$ Andina Putri Aulia \\ ${ }^{1}$ Department of Biochemistry, Faculty of Medicine, UNISSULA, Semarang \\ ${ }^{2}$ Department of Pathology Clinic, Faculty of Medicine, UNISSULA, Semarang \\ *e-mail : hestywahyuningsih15@gmail.com
}

\begin{abstract}
Red cabbage (Brassica oleracea var. Capitata f. Rubra) is a vegetable widely used in Indonesian cuisine. Red cabbage is rich in anthocyanins so it can be used to reduce SGPT levels in drug induced liver injury (DILI). This study aims to determine the effect of red cabbage juice on SGPT levels in acetaminophen-induced liver injury. The methods In this post-test only control group study, male Wistar rats (300g) were randomly divided into 5 groups (K1-K2-K3-K4-K5). Acetaminophen was given to induce liver injury in rats. The rats were treated with the cabbage juice (at the dose of $0.5 \mathrm{~g} / \mathrm{ml} \mathrm{or} 0.7 \mathrm{~g} / \mathrm{ml} \mathrm{or} 0.9 \mathrm{~g} / \mathrm{ml} . \mathrm{Data}$ were analyzed using One way ANOVA and LSD post hoc test. The results Mean SGPT levels for K1, K2, K3, K4, K5 was $58.43 \pm 7.18 \mathrm{UI} / \mathrm{L}, 71.20 \pm 9.13 \mathrm{UI} / \mathrm{L}, 55.73 \pm 9.51 \mathrm{UI} / \mathrm{L}, 72.80 \pm 3.47 \mathrm{UI} / \mathrm{L}, 72.63 \pm 3.01 \mathrm{UI} / \mathrm{L}$, respectively. One way ANOVA resulted in $p=0.00$ ( $p<0.05)$. The post hoc LSD test showed a significant differences $(P<0.05)$ between all groups except between groups K1-K3,K2-K4 and K2-K5 ( $p>0.05$ ). the conclusion Red cabbage juice can reduce SGPT in acetaminophen induced liver injury in rats. The most effective dose was $0.5 \mathrm{~g} / \mathrm{ml}$.
\end{abstract}

Keyword : Red Cabbage, Acetaminophen, DILI, SGPT

\section{INTRODUCTION}

Red cabbage (Brassica oleracea var. capitata f. rubra) is a group of vegetables that have many benefits for the body. Cabbage has several variations, including white cabbage and red cabbage. Red cabbage is rich in anthocyanins, which is a subclass of flavonoids that have beneficial for treating and preventing inflammation. The levels of anthocyanins in red cabbage are higher than in white cabbage, so people have long used red cabbage as traditional medicine (Pandey and Rizvi, 2009).

Drug-induced liver injury (DILI) is a condition of liver damage caused by using drugs that are not following the rules of use. In Indonesia, DILI is an iceberg phenomenon that will affect morbidity and mortality rates. Recently, red cabbage extract has also been proven to be a hepatoprotection (ElMotaleb el-Mowafy, 2012). In the previous studies, the use of methanol content for extract making has a toxic effect if used for more than $240 \mathrm{ml} / \mathrm{kg}$, the use of the extract is still classified as difficult to apply in the community, and the use of red cabbage juice needs to be considered (Ashurst and Nappe, 2018). The use of juice can increase anthocyanin levels in plasma so that it will increase the effectiveness of antioxidants (Zeitschrift, 2014).

The liver is one of the largest organs in the body with the main function of the metabolism of various substances and detoxification. Due to continuously exposed to toxic substances such as drugs, the liver can experience anatomical, physiological, and histological disorders due to inflammatory reactions and oxidative stress experienced by the liver cells. This disorder is called drug-induced liver injury (DILI). The diagnosis of DILI can be made by increasing levels of glutamic pyruvic transaminase serum and glutamic oxaloacetic transaminase serum by more than three times the normal limit valuations (Wolkoff, 2010). Acetaminophen is a type of drug that is hepatotoxic. The use of acetaminophen as an antipyretic and analgesic drug in society is still high. The incidence of DILI in Iceland reaches $19.1 \%$ per 100,000 
population, while in France the incidence of DILI reaches $13.9 \%$ of cases per 100,000 population (Licata et al., 2017). The incidence of DILI in Indonesia, which was recorded by the Food and Drug Administration (BPOM) in 2002-2005, was 175 DILI cases due to acetaminophen induction out of 201 DILI cases in total. However, Cahaya and Mutia's research (2014) shows that drug trends that cause DILI are different in each region. The use of hepatotoxic drugs in Indonesia is still high, in Bandung, the use of hepatotoxic drugs is $80.4 \%$ and the most frequently used drug is acetaminophen, which is $22 \%$. Incomplete data collection on all DILI cases with lack of regulation and medication adherence allows the number of patients with DILI due to the induction of acetaminophen is bigger than the data collection, which will increase morbidity and mortality. Therefore, further research is needed to reduce morbidity and mortality due to DILI (Cahaya and Mutia, 2014).

The use of acetaminophen that not following doctor's recommendations can cause liver toxicity and induce the production of various enzymes such as Serum Glutamic Pyruvic Transaminase (SGPT), Serum Glutamic Oxaloacetic Transaminase (SGOT), Alkali Phosphatase (ALP), and gamma-glutamyl transferase (YGT). The increase in these enzymes indicates cellular leakage and cellular damage to the liver function due to the increase in Reactive Oxygen Species (ROS) induced by $\mathrm{N}$-acetyl-benzo-quinoneimine (NAPQI). NAPQI is a toxic metabolite of acetaminophen. An increase in NAPQI can occur due to an imbalance in the amount of NAPQI and glutathione. This condition can be prevented by giving antioxidants, one of which is anthocyanins. Anthocyanins have properties as hepatoprotector by reducing oxidants and increasing glutathione, which can deplete NAPQI thereby reducing inflammatory reactions in the liver. SGPT levels are more sensitive to liver damage (Yoon et al., 2016). Previous research has shown that the anthocyanin content in roselle flowers can act as a hepatoprotector (Suganda, G., 2010).

Flavonoids are pigment compounds in plants that are synthesized from phenylalanine. Flavonoids have benefits like antioxidants, anti-inflammatory, and anti-allergic. Red cabbage (Brassica oleracea var.
Capitata f. Rubra) is also a plant that is rich in anthocyanins with levels of $63.50 \mathrm{mg} / 100 \mathrm{~g}$ foodstuffs (Kozłowska and Szostak-węgierek, 2014). Anthocyanins are a subclass of flavonoids. Based on research by El-Motaleb el-Mowafy (2012), red cabbage extract with or without cysteine has been shown to reduce levels of SGPT, serum glutamic oxaloacetic transaminase (SGOT), alkaline phosphatase (ALP), and gamma-glutamyl transferase (GGT) in white albino rats which were induced by acetaminophen $2 \mathrm{~g} / \mathrm{kg}$ for 60 days. However, research on the effectiveness of red cabbage juice as a hepatoprotective effect is still restricted. Therefore, this study wanted to prove whether red cabbage juice could affect SGPT levels in acetaminophen-induced liver damage.

\section{MATERIAL AND METHODS}

This is experimental research with a post-test control group design which was carried out in November-December 2018. This research has received approval from the Bioethics Commission of the Faculty of Medicine UNISSULA with ethical clearance No.357/IX/2018/Komisi Bioetik. The sample consisted of 30 male Wistar rats kept in the Experimental Animal Laboratory of the Faculty of Medicine Diponegoro University, Semarang, which were divided into 5 groups. The first group (K1) is a negative control group; male Wistar rats fed standard feed for 14 days. Group 2 (K2) was a positive control test group; male Wistar rats fed standard feed, distilled water, and acetaminophen. Group 3 (K3) was the first treatment group; the rats were given standard feed, distilled water, red cabbage juice with a dose of $0.5 \mathrm{~g} / \mathrm{ml}$, and acetaminophen. Group 4 (K4) is the second treatment group; male Wistar rats given standard feed, distilled water, red cabbage juice at a dose of $0.7 \mathrm{~g} / \mathrm{ml}$, and acetaminophen. Group 5 (K5) is the treatment test group 3; male Wistar rats given standard feed, distilled water, red cabbage juice at a dose of $0.9 \mathrm{~g} / \mathrm{ml}$, and acetaminophen. Standard distilled water was given for 14 days. Acetaminophen was given twice with 16 hours' time period for each administration. SGPT level was analyzed using an Alanine aminotransferase activity assay kit at the 
Sultan Agung Islamic University Laboratory, Semarang.

The independent variable of this study was red cabbage juice (Brassica oleracea var. capitata f. rubra). Red cabbage juice is a piece of local red cabbage leaves that cut into small pieces and scaled as much as 50 grams for a dose of $0.5 \mathrm{~g} / \mathrm{ml}, 70$ grams for a dose of $0.7 \mathrm{~g} / \mathrm{ml}$, and 90 grams for a dose of 0.9 $\mathrm{g} / \mathrm{ml}$. Each added $100 \mathrm{ml}$ of distilled water at room temperature, then blended to smooth and filtered until there are no macro-sized residues. Each dose of red cabbage juice was given to mice with $2.5 \mathrm{ml}$ of stomach swab twice a day in the morning and evening. The dependent variable of this study is the level of SGPT. SGPT level within $\mathrm{mg} / \mathrm{dl}$ units in blood samples of male Wistar rats was taken from the ophthalmic vein. The precondition variable of this study was the provision of acetaminophen to increase SGPT levels. Acetaminophen is given $3 \mathrm{ml}$ with a dose of $300 \mathrm{mg}$ with a span of 16 hours orally to cause liver damage.

The decision of the dose of acetaminophen in male Wistar rats based on the research of Iyanda and Adeneyi (2011); a dose of $1000 \mathrm{mg} / \mathrm{kg}$ of acetaminophen in 16 hours can cause microsomal damage to the liver and increasing liver enzymes. The dose given to mice that weighed 300 grams is $300 \mathrm{mg}$. The acetaminophen was used in a drop dosage form (Sanmol drop) containing $60 \mathrm{mg}$ per 0.6 $\mathrm{ml}$.

The data obtained was carried out by a descriptive test to determine the mean and standard deviation. After the descriptive test, the normality test is applied using the Shapiro-Wilk test, and the homogeneity examined by the Levene test with a normal and homogeneous distribution. Furthermore, the one-way ANOVA test resulting in $\mathrm{p}<0.05$, followed by the LSD posthoc test.

\section{RESULTS AND DISCUSSION}

The research data obtained were the SGPT levels of all research subjects. The mean SGPT levels in the 6 groups are described in Figure 1.

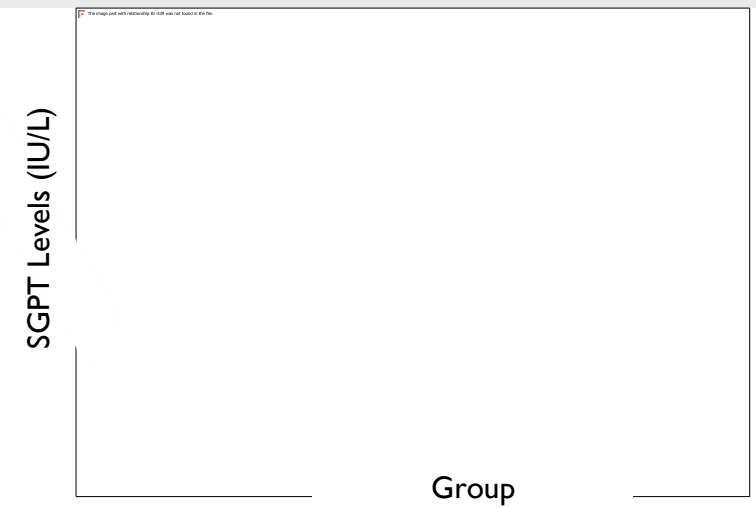

Figure 1. The graph of the mean SGPT level bar. K1: negative control, K2: positive control, K3: dosage 0,5 $\mathrm{g} / \mathrm{ml}, \mathrm{K} 4$ : dosage $0,7 \mathrm{~g} / \mathrm{ml}, \mathrm{K} 5$ : dosage $0,9 \mathrm{~g} / \mathrm{ml}$

Based on Figure 1, it is shown that the mean SGPT level in the negative control group (K1) was 58.44 UI / L, while the mean positive control group (K2) was $71.20 \mathrm{UI} / \mathrm{L}$. In the treatment group, the lowest average was in the group with red cabbage juice $0.5 \mathrm{~g} / \mathrm{ml}$ with a mean of $55.74 \mathrm{IU} / \mathrm{L}$. The distributions of the SGPT levels data from the five groups were analyzed using the Shapiro-Wilk test, while the homogeneity by the Levene test. The results of the normality test in the five research groups are shown in Table 1.

Table 1. Results of the normality test of Saphiro-

Wilk and Levene test

\begin{tabular}{ccc}
\hline Group & $\begin{array}{c}\text { Normality Test } \\
\text { Result }\end{array}$ & $\begin{array}{c}\text { Levene Test } \\
\text { Result }\end{array}$ \\
\hline K1 & $0,264^{*}$ & $0,054^{*}$ \\
K2 & $0,106^{*}$ & \\
K3 & $0,870^{*}$ & \\
K4 & $0,443^{*}$ & \\
K5 & $0,593^{*}$ & \\
\hline
\end{tabular}

Note: $*=$ normal and homogeneous data distribution $(\mathrm{p}>0.05)$

The results of the normality test on the five data obtained normal data distribution results with ( $>0.05$ ). The results of the homogeneity test with the Levene test showed p results of 0.054 ( $p>0.05$ ), which indicates that the variance of the SGPT data in the five groups was homogeneous.

SGPT levels from the five groups met the requirements for a parametric test with the one-way 
ANOVA test. The results of the one-way ANOVA test are shown in table 2 .

Table 2. One-way ANOVA hypothesis test results

\begin{tabular}{lcc}
\hline \multicolumn{1}{c}{ Group } & $\begin{array}{c}\text { Mean }(\mathbf{U I} / \mathbf{L}) \pm \\
\text { SD }\end{array}$ & $\begin{array}{c}\text { P } \\
\text { value }\end{array}$ \\
\hline $\begin{array}{l}\text { Negative } \\
\text { control (K1) }\end{array}$ & $58,43(7,18)$ & $0,000^{*}$ \\
$\begin{array}{l}\text { Positive } \\
\text { control (K2) }\end{array}$ & $71,20(9,13)$ & \\
$\begin{array}{l}\text { Dosage 0,5 } \\
\text { g/ml (K3) }\end{array}$ & $55,73(9,51)$ \\
Dosage 0,7 \\
g/ml (K4) \\
$\begin{array}{l}\text { Dosage 0,9 } \\
\text { g/ml (K5) }\end{array}$ \\
\hline
\end{tabular}

Note: $*=$ significant difference $(\mathrm{p}<0.05)$

The results of the one-way ANOVA test with a value of $p=0.000(p<0.05)$ showed that at least two groups of data had significant mean differences. Furthermore, the LSD post hoc test was conducted to determine which groups had significant differences. The results of the post hoc LSD test are shown in table 3.

Table 3. Post hoc LSD test result

\begin{tabular}{cccccc}
\hline Group & $\mathrm{K} 1$ & $\mathrm{~K} 2$ & $\mathrm{~K} 3$ & $\mathrm{~K} 4$ & $\mathrm{~K} 5$ \\
\hline $\mathrm{K} 1$ & - & $0,004^{*}$ & 1,512 & $0,002^{*}$ & $0,002^{*}$ \\
$\mathrm{~K} 2$ & $0,004^{*}$ & - & $001 *$ & 0,695 & 0,726 \\
$\mathrm{~K} 3$ & 0,512 & $0,001^{*}$ & - & $0,000^{*}$ & $0,000^{*}$ \\
$\mathrm{~K} 4$ & $0,002^{*}$ & 0,695 & $000^{*}$ & - & 0,966 \\
$\mathrm{~K} 5$ & $0,002^{*}$ & 0,726 & $000^{*}$ & 0,966 & - \\
\hline \multicolumn{7}{c}{ Note: * significant difference $(\mathrm{p}<0.05)$}
\end{tabular}

Based on the results of the posthoc LSD test in table 3 , it shows that there is a significant difference ( $\mathrm{p}<0.05$ ) between $\mathrm{K} 1$ and $\mathrm{K} 2$, between $\mathrm{K} 1$ and $\mathrm{K} 4, \mathrm{~K} 1$ and $\mathrm{K} 5$, between $\mathrm{K} 2$ and $\mathrm{K} 3$, between $\mathrm{K} 3$ and $\mathrm{K} 4$, also between $\mathrm{K} 3$ and $\mathrm{K} 5$. However, there was no significant difference ( $p>0.05$ ) between K1 and $\mathrm{K} 3$, between $\mathrm{K} 2$ and $\mathrm{K} 4$, also $\mathrm{K} 4$ and $\mathrm{K} 5$.

Anthocyanins are the colors of orange, red and purple in fruits and vegetables. Apart from being a color giver for fruits and vegetables, anthocyanins also have benefits as anti-inflammatory, anti-cancer, anti-obesity, anti-diabetic, neuroprotective, and antioxidant (Li et al., 2017). Flavonoids act as antioxidants and anti-inflammatory by inactivating carcinogens, inhibiting cell proliferation, accelerating DNA repair, and reducing oxidative stress (Kozłowska and Szostak-węgierek, 2014). Anthocyanins are a subclass of flavonoids that can act as a potent anti-inflammatory. The anthocyanin structures found in red cabbage are Cyanidine-3-Odiglucoside-5-O-glucoside, Cyanidine-3-O-(pcoumaroyl) diglucoside-5-O-glucoside, Cyanidine-3O-(feruloyl) diglucoside-5-O-glucoside, Cyanidine-3O-(sinapoyl) diglucoside-5-O-glucoside, and Cyanidine-3-glucoside. This structure can reduce free radicals and trigger the formation of glutathione (GSH) (Zhang et al., 2017).

Based on previous research regarding red cabbage extract made with $600 \mathrm{ml}$ of $80 \%$ methanol, it is proven to have a hepatoprotector effect (ElMotaleb el-Mowafy, 2012). However, the use of alcoholic substances in the manufacture of extracts can reduce oxidant absorption so that it will reduce the effect of antioxidants (Waszkowiak and Gliszczyńska-Świgło, 2016). Previous research on the effectiveness of antioxidants and anthocyanin components in red berry juice shows that giving red berry juice can increase anthocyanin absorption because the administration in the form of juice will increase the active component of anthocyanins in plasma so that it will increase the antioxidant effect (Zeitschrift, 2014). The anthocyanin components in red cabbage and red berries are the same, therefore it is possible to use red cabbage in the form of juice to increase the effect of anthocyanins. In previous studies, giving red cabbage juice with a concentration of $50 \%, 70 \%$, and $90 \%$ can reduce body weight, total cholesterol, and LDL (Wulandari, 2015).

The results of this study indicate that red cabbage juice can reduce SGPT levels in Wistar rats induced by acetaminophen as evidenced by the oneway ANOVA test with a value of $\mathrm{p}=0.000$ ( $\mathrm{p}$ $<0.05$ ). This is supporting the research of El-Motaleb el-Mowafy (2012) which shows the effect of anthocyanins in red cabbage extract on SGPT levels of Wistar rats. The effect of anthocyanins on SGPT levels in Wistar rats was also proven by research by Elijah et al. (2017) which proved that there was a significant decrease in SGPT levels in Wistar rats induced by acetaminophen at a dose of $750 \mathrm{mg} / \mathrm{kg}$ after being given rosella flower extract. The 
components of Cyanidine-3-O-diglucoside-5-Oglucoside and Cyanidine-3-glucoside found in red cabbage anthocyanins can bind ROS and enhance GSH production, which will reduce NAPQI levels and reduce inflammation in hepatocytes that are marked by a decrease in SGPT levels (Wiczkowski et al., 2013; Wang et al., 2017).

After the post hoc test was carried out, there was a significant difference between the positive control group and the negative control group ( $p$ $<0.05$ ) indicating that the administration of acetaminophen at a dose of $300 \mathrm{mg}$ twice in 16 hours could increase ALT levels. This increase is due to the administration of $300 \mathrm{mg}$ acetaminophen 2 times with a period of 16 hours which can cause mild liver damage that is marked by an increase in liver enzymes, one of which is SGPT (Iyanda, A. and Adeniyi, F., 2011). Mild liver damage that results from taking excessive doses of acetaminophen is called DILI. The use of excessive doses of acetaminophen can lead to GSH depletion increasing NAPQI metabolites. The binding of NAPQI with hepatic cells results in an inflammatory reaction which can induce the release of ROS resulting in cellular damage. Cellular damage to the liver promotes the release of hepatic enzymes, one of which is SGPT (Yoon et al., 2016).

There was a significant difference between $\mathrm{K} 2$ and $\mathrm{K} 3$ with a value of $\mathrm{p}=0.001(\mathrm{p}<0.05)$, while there was no significant difference between $\mathrm{K} 1$ and K3 with $p=0.512$ ( $p>0.05$ ). These show that clinically, red cabbage juice at a dose of $0.5 \mathrm{~g} / \mathrm{ml}$ can reduce the SGPT levels of male Wistar rats induced by acetaminophen due to the anthocyanin content of red cabbage.

Statistically, there is a significant difference between K4 and K5 on K3 with a value of $p=0.000$ $(\mathrm{p}<0.05)$ and $\mathrm{p}=0.000(\mathrm{p}<0.05)$. There was no significant difference between groups $\mathrm{K} 4$ and $\mathrm{K} 5$ against $\mathrm{K} 2$ with a value of $\mathrm{p}=0.695(\mathrm{p}>0.05)$ and $\mathrm{p}=$ $0.726(\mathrm{p}>0.05)$. These data indicate that clinically there was an increase in SGPT levels in Wistar rats induced by red cabbage juice at a dose of $0.7 \mathrm{~g} / \mathrm{ml}$ and $0.9 \mathrm{~g} / \mathrm{ml}$ close to SGPT levels in rats that given acetaminophen only. Based on research by Nielsen et al. (2003) conducted on animals that given purified blackcurrant juice at a dose of $256 \mathrm{mg}$ /animal that had lower plasma Cyanidine-3-glucoside levels than animals which received a dose of $182 \mathrm{mg} /$ animal, this shows that the higher the concentration of anthocyanins given, the lower the absorption of the component. The use of antioxidants at high doses can cause changes in the effect of antioxidants into prooxidants and disrupt the stability of cell redox reactions that will increase the concentration of ROS. Increased ROS can cause cell mitochondrial dysfunction, which can lead to cell damage and cell death (Bohn and Bouayed, 2010). Based on statistical data and existing theory, it concluded that clinically, giving red cabbage juice at high doses can cause an increase in ALT levels.

\section{CONCLUSION}

Red cabbage juice is a vegetable that contains anthocyanins which can function as antioxidants. The administration of red cabbage juice can reduce SGPT levels in male Wistar rats that have liver damage due to acetaminophen induction, the most effective dose is $0.5 \mathrm{~g} / \mathrm{ml}$. It is suggested that further research on quantitative research based on the concentration of anthocyanin content in red cabbage juice, research on anthocyanin activity in red cabbage juice with parameters 1,1-diphenyl-2-picrylhydrazyl (DPPH) and malondialdehyde (MDA), research on the toxicity of red cabbage juice, and studies with other parameters such as immunohistochemistry (IHC) and histopathology.

\section{ACKNOWLEDGEMENT}

We would like to thank the Institute for Research and Community Service (LPPM) Sultan Agung Islamic University for funding this research. Also, to all those who have helped this research to completion.

\section{REFERENCES}

Ashurst, V.J., dan Nappe, M.T., 2018, Methanol Toxicity, Stat Pearls Publishing.

Bouayed, J. dan Bohn, T., 2010, Exogenous Antioxidants Double-edged Swords in 
Cellular Redox State, Health Beneficial Effects at Physiologic Doses Versus Deleterious Effects at High Doses, Oxidative Medicine and Cellular Longevity, 228-237.

Cahaya, N., dan Mutia, R., 2014, Evaluasi ObatObatan Berpotensi Hepatotoksik pada Pasien Dengan Gangguan Fungsi Hepar di Ruang Rawat Inap RSUD Ulin Banjarmasin, 16-26.

El-Motaleb el-Mowafy, M.A., 2012, Treatment Effect of Red Cabbage and Cysteine Against Paracetamol Induced, 5852-5859.

Elijah, J. P., Ukegbu, C. Y.,Eze. C., Nkwocha, C. C., Okafor, J. O., Amaechi, O., Nduka, F. O., Ozougwu, V., Eyenike, J. O., Ugochukwu, N. E., 2017, Biochemical Effects of the Aqueous Extract of Hibiscus sabdariffa on Liver Marker and Lipid Profiles in Acetaminophenchallenged Rats, Research Journal of Medical Plant, 49-54.

Iyanda, A. A. dan Adeniyi, F. A. A., 2011, Biochemical and Histologic Presentations of Female Wistar Rats Administered With Different Doses of Paracetamol / Methionine, 151-160.

Kozłowska, A. dan Szostak-węgierek, D., 2014, Flavonoids - Food Sources and Health Benefits, 79-85.

Li, D., Wang, P., Luo, Y., Zhao, M., Chen, F., 2017, Health Benefits of Anthocyanins and Molecular Mechanisms: Update From Recent Decade, Critical Reviews in Food Science and Nutrition, Taylor \& Francis, 1729-1741.

Licata, A., Minissale, M.G., Calvaruso, V., Craxl, A., 2017, A Focus on Epidemiology of DrugInduced Liver Injury: Analysis of $A$ Prospective Cohort, 112-121.

Nielsen, I., Inge, L., Dragsted, L., Ravn-Haren, G., Freese, R., Rasmussen, S., 2003, Absorption and Excretion of Black Currant Anthocyanins in Humans and Watanabe Heritable Hyperlipidemic Rabbits, Journal of agricultural and food chemistry, 51, 28132820.

Pandey, K.B. dan Rizvi, S.I., 2009, Plant Polyphenols as Dietary Antioxidants in Human Health and Disease, 270-278.

Suganda, G., 2010, Rosella Hibiscus sabdariffa L.
Serial Data Ilmiah Terkini Tumbuhan Obat, Badan Pengawas Obat dan Makanan Deputi Bidang Pengawasan Obat Traditional, Kosmetik dan Produk Komplemen Direktorat Obat Asli Indonesia, 8-9.

Waszkowiak, K. dan Gliszczyńska-Świgło, A., 2016, Binary Ethanol-Water Solvents Affect Phenolic Profile and Antioxidant Capacity of Flaxseed Extracts, European Food Research and Technology, 242(5), 777-786.

Wolkoff, A. W., 2010, Disorders of The Liver and Biliary Tree, Approach to Pthe Patient with Liver Disease, Harrison's Gastroenterology and Hepatology, Editor Dan L. L dan Anthony, S.F., McGraw-Hill Education dan EGC Medical Publiser, 340-384.

Wulandari, T., 2015, Pengaruh Jus Kubis Merah dalam Menurunkan Kadar Kolestrol dan Berat Badan Tikus Putih, Skripsi, Universitas Sebelas Maret, Surakarta.

Yoon, E., Babar, A., Choudhary, M., Kutner, M., Pyrsopoulus, N., 2016, AcetaminophenInduced Hepatotoxicity: a Comprehensive Update, Journal of Clinical and Translational Hepatology, 4(2), 131-142.

Zeitschrift, D.L., 2014, Anthocyanin Content and Antioxidant Activity of Various Red Fruit Juices.

Zhang, J.I.E., Wang, Z., Liu, X., 2017, Characterization Of Acylated Anthocyanins In Red Cabbage Via Comprehensive TwoDimensional High Performance Liquid Chromatography and HPLC-MS, 1-7. 